\title{
DEVELOPING MULTIMEDIA-BASED LISTENING MATERIALS FOR THE TENTH GRADE STUDENTS
}

\author{
Curnia Karim \\ Yogyakarta State University, Jl. Colombo No.1, Yogyakarta, Indonesia \\ curnia.karim@yahoo.co.id, \\ Dyah Setyowati Ciptaningrum, Ed.D \\ Yogyakarta State University, Jl. Colombo No.1, Yogyakarta, Indonesia \\ dyah_ciptaningrum@uny.ac.id
}

\begin{abstract}
This study aimed at developing the supplementary multimedia-based listening materials for tenth grade students in the first semester using scientific approach Curriculum of 2013. This study was research development using the model by Brach (2009) and was conducted at MAN 1 Pamekasan. The final product of this study was in a macro-media flash file attached inside CDs. The result of the product evaluation and try-out showed that the materials were interestingly presented in terms of topics and listening activities. Moreover, it was also able to motivate students to learn listening.
\end{abstract}

Keywords: Multimedia-based listening materials, scientific approach, listening activities, curriculum of 2013.

\section{A. INTRODUCTION}

Indonesian government has gradually developed and modified the curriculum to meet the needs of students and the relevance to the current condition in the world. The current curriculum in Indonesia is curriculum of 2013. Curriculum of 2013 has been developed by the theory of the competency-based curriculum which engages the students to widely improve their competence, knowledge, and positive attitude (spiritual and social values). This curriculum provides the students with integrated materials to actively participate in the process of learning and teaching English. In order to improve the students' competence, knowledge, and positive attitude, the teachers has to be creative in teaching process which can use technology as a media. Technology helps people to know the information quickly as soon as they need. In education environment, technology has contributions for teachers as it could serve an interesting way of teaching. In this case, the teacher's role is as a motivator and facilitator. The teacher need a media to make students can regulate their learning. One of the efforts to improve the quality of teaching can be performed by implementing the innovation learning, by utilizing the tool technology called with Information and Communication Technology (ICT) (Muslimin, 2011).

At this point in time, most of secondary school facilitated the computer laboratory, but the existence of computer laboratory is not optimally used to help the teacher in the teaching and learning process. In addition to the absence of instructional technology approaches in the 
development of learning instruments, the researcher discovered other problems in English language learning in middle schools, one of which was that most of listening materials were in the form of $\mathrm{mp} 3$ format or the teacher herself narrates the script. The teacher usually plays the listening materials in the classroom by using LCD and audio speaker. According to the students, the listening materials were less interesting because they only have a chance to listen and do the exercises. They prefer multimedia listening materials to help them understand better and reduce their anxiety.

The unavailability of teaching materials with audio-based media is an important problem because audio provides listening input and will become the base for elevating other language skills such as reading, speaking which includes pronunciation, and writing (Dunkel, 1993). The unavailability of audio-based media is inappropriate with the standards of the current curriculum which contains the basic competence standards of listening and states that students are expected to be able to understand meaning in very simple transactional and interpersonal conversation to interact within their environment. As such, the curriculum regards listening skills as a basic competence that students need to possess. Listening involves making sense of the meaningful sounds of the language by using context and knowledge of the language and the world (Spratt, Pulverness, \& Williams, 2005).

There are many kinds of multimedia-based materials that might be implemented in teaching listening skills. By using multimedia, the students can be motivated to learn, because they can listen to audio, watch the video or view the text, animation and graphics simultaneously. Listening is a skill that needs training on an ongoing basis to the students, while in the process of teaching and learning, listening activities are often ignored by teachers because they tend to assume that listening is automatically done by the students. In addition, there is no also attention to use the other media, such as multimedia-based materials that can improve the quality of teaching. In order to overcome the problems faced by students, it is necessary to design teaching materials for the listening skills which are equipped with multimedia-based materials that can assist students to more easily understand the speech heard.

\section{B. REVIEW OF LITERATURE}

\section{Multimedia-based listening materials}

One of the strategies to improve the quality of learning is by utilizing Information Communication Technology (ICT) via interactive multimedia Prabhu (2011). For the aspects of learning, learning outcome improvement is supported by the use of media of instruction. 


\section{Curnia Karim, Dyah Setyowati, Developing Multimedia-Based Listening...}

Through the media, the potential sense of students can be accommodated. One of the aspects of leading media that can improve learning outcomes is the multimedia. Information and Communication Technology (ICT) is the forms of technology used for creating, displaying, storing, manipulating, and exchanging information (Meleisea, 2007, cited in Nguyen, Williams \& Nguyen, 2012). Owing to the above, there is widespread change across the world to infuse ICT into education. Teacher education institutions may have to prepare teachers to teach integrating ICT into their teaching. One of the strategies to improve the quality of learning is by utilizing Information Communication Technology (ICT) via interactive multimedia.

In recent years, multimedia has introduced the pedagogical strength in facilitating student learning and supplementing learning with liveliness as it adds richness and meaning to the information presentation with the use of more than one medium (Shank, 2005). Multimedia as the use of several different types of media for a single purpose, e.g as in a video that uses film, audio, sound effects, and graphic images. In brief, multimedia is the combination of several media like text, sound, art, animation, and the like which presenting information through computer technology (Richards \& Schmidt, 2010). Multimedia becomes interactive when the users of multimedia application can control what and when some parts of the application contents will be delivered (Vaughan, 2008).

Interactive multimedia has the potential to create important standard learning environment which actively employ the learner, thereby promoting deep learning (Cairncross \& Mannion, 2001). The elements in multimedia provide the message and the delivery which directs to a better learning and teaching environment. The use of multimedia as an effective teaching and learning tool, he stated that the promise of multimedia learning is that teachers can tap the power of visual and verbal forms of expression in the service of promoting student understanding (Mayer, 2009). On the other hand, some advantages of using interactive multimedia also exist. First, it can increase the number of information, save time, and improve class efficiency. Second, it enables students to get feedback directly, to know about their learning results and to adjust their learning steps. Third, teachers can integrate materials and present them with a variety of information under the help of multimedia. Fourth, it helps to develop students' associative thinking. Fifth, it provides an idea for the communication between teachers and students as well as students and students.

Interactive multimedia can bring positive effects to the students in the teaching learning process. The developer should be serious in selecting the software based on its quality and specification. Therefore, knowing the criteria and quality of interactive multimedia is the best solution. There are some guidelines for the design of various types of instructional multimedia 
Volume 5, Number 01, June 2019

(Stemler, 1997). They are the screen design, interaction, feedback, navigation, learner control, colour, graphic, animation, audio, and video.

\section{Scientific approach}

The students in the level of secondary school are expected to achieve informational level, because they are prepared for taking higher education. Epistemic level is considered too demanding for Senior High School students because in Indonesia, English functions as a foreign language.

As an institution which has regulation to manage the curriculum, it has released a new curriculum called Curriculum 2013. According to The Ministerial Regulation No. 65 of 2013 regarding standard process, learning goals in the Curriculum 2013 cover students' development in three aspects which are attitudes, knowledge and skills. Based on the Standard of Contents, Curriculum 2013 covers interpersonal and transactional communications in a variety of contexts for varied purposes using a range of text types and language functions. The contents also include knowledge about text features such as social function, text structure, grammar, and vocabulary and values.

According to the Ministry of Education and Culture, Curriculum 2013 consists of core competences (Kompetensi Inti/KI) and basic competences (Kompetensi Dasar/ KD). The $\mathrm{KI} / \mathrm{KD}$ for grade X students are described in appendix. Based on the "Kemendikbud's" book entitled "Materi Pelatihan Guru Implementasi Kurikulum 2013", the steps of teaching are: introduction activity, core activity (observing; questioning; collecting data, analyzing data, and communicating; creating), and closing activity (Kemendikbud, 2013).

\section{a. Introduction Activity}

The teacher will prepare the students to face learning process physically and mentally. This involves activities like greeting and asking questions about the previous lesson and asking about the topic that is going to discuss. These questions should lead the students related to the topic. If the students seem not ready to study, the teacher has to motivate them first. As they have been to be motivated, the teacher will introduce the topic and tell the objectives of the teaching learning process. Then the teaching is going to the warm-up activity.

\section{b. Core Activity}

The teacher applies core activities. This step is the main learning process. The purpose of this step is to achieve learning basic competence stated. The characteristics of the activity are interactive, inspiring, enjoying, challenging, and motivating; while, its objectives are to encourage students to find much information, and give them freedom to be creative and autonomous based on talent and their interesting, both physically and psychologically. 


\section{Curnia Karim, Dyah Setyowati, Developing Multimedia-Based Listening...}

In order to achieve the goals of core activities, teaching English at secondary school nowadays uses Scientific Approach. This approach has five phases; observing, questioning; collecting data, analyzing data, and communicating; and creating. All of the phases belong to core activity. In the first phases, the teacher will ask the students to observe about the topic given. The teacher will try to make the students wonder about the topic. The goal of this activity is to train the sincerity, carefulness, and to collect the information. The second phase is questioning activities. In this activity, the students will be required to make some questions about the topic that appear during observation activity. The goal of this activity is to develop curiosity, creativity, the ability to formulate questions in order to create a critics' mind that is educated and want to learn more. The next phase is collecting data, analyzing data, and communicating. In this activity, the students will be asked to collect as much as information about the topic, and analyze the information they get, and then communicate the result with others. The information can be obtained from searching information on the internet, reading the other sources, or interviewing. The information should be relevant and easy to be comprehended. The main goal of this activity is to apply the ability to collect information. The last activity is creating. Here, the students will create their information with their own word. The main goal of this activity is to develop the ability to show the opinion briefly and clearly, and to develop the ability to write and speak correctly and fluently. The teachers may lead the students to create by designing guided, semi-guided, and free language production tasks.

\section{c. Closing Activity}

The last teaching activity is closing activities. In this step, the teacher together with the students concludes the lesson. There are also activities in which the teacher evaluates the students learning progression and prepares plan to improve the students' weakness on the lesson taught whether the students need more remedial, assignment, or counselling.

\section{Listening activities}

Teaching a language is essentially taught to communicate. Therefore, language teaching is to improve students' ability to communicate both oral and written forms. But, to be able to communicate well, students must have language skills. Listening is one of the skills in language teaching that should be taught, before speaking, reading and writing (O'Connor, 1998). Listening comprehension as the process of understanding speech in a first or second language which focuses on the role of individual linguistic units (e.g. phonemes, words, grammatical structures) as well as the role of the listener's expectations, the situation and context, background knowledge and topic (Richards \& Schmidt, 2010). 
Volume 5, Number 01, June 2019

There are some stages in doing a listening comprehension (Field, 2008). Those stages are 1) pre-listening. This stage is the introduction of the listening activity in which the students will make a preparation about what they are going to listen. The teachers may presented the news items of vocabulary that the students were about to encourage in the recording. 2) listening. It is the main activity of listening. The students listen to the recording and get the main idea of it. The important thing is that the students can understand the content of the recording. There are two types of listening activities. The first is extensive listening in which the listening activities followed by the general questions on the context. The second is intensive listening in which the listening activities followed by detailed comprehension questions. 3) post-listening. After the students understand about the content of the recording and do the activities given, the teachers checked the answers to comprehension questions and explored the language of listening. The teachers may teach any new vocabulary, analyse the language, or paused play the recording in which the students may listen to the recording and repeat any new vocabulary.

Material for listening skills would be interesting to learners in accordance with their level. the exercises for listening skills are more effective if they can understand what have been demonstrated (Ur, 1984). Therefore, it is advisable to involve students with different types of input, such as video, audio, text or animation. The students require vary activities to enhance their comprehension of listening skill. During this time, the learning media in the listening skill consist of audio and text, followed by exercises. Such learning media make the students bored, because there is the lack of variation, such as the use of video, audio, text or animation. The listener uses what the context of communication to predict what the message will contain, and uses parts of the message to confirm, correct or add to this. The key process is how the listener infers the meaning of the input.

\section{METHOD}

This study employed research and development $(\mathrm{R} \& \mathrm{D})$ design which aimed to develop supplementary media-based listening materials for the tenth graders in the first semester. The researcher adapted ADDIE model (Branch, 2009). The subjects of this study were the tenth grade students of MAN 1 Pamekasan. The population of the tenth graders was five classes. . In this study, the researcher used simple random sampling which involved the random selection of individuals from the realistic population as a whole.

The research procedure in this study was use ADDIE model which proposed by Branch. It has five-step process that goes through the following steps; analysis, design, development, 
implementation, and evaluation. The scheme of the steps of the ADDIE design model in this study is shown in figure 1 below.

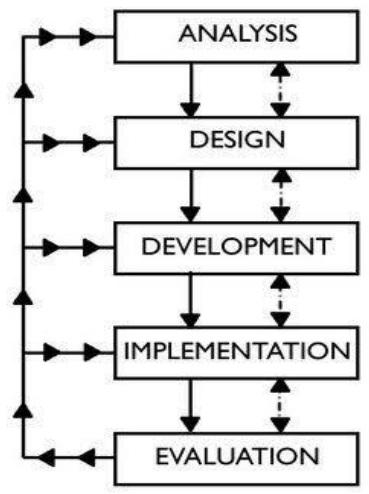

Figure 1. A materials Design Model by ADDIE by Branch

1. Analysis. In this step, the researcher conducted an interview, observation, and need analysis in order to find out some information that can be very useful as the consideration to conduct the next step. Those kinds of analyses were evaluated by the expert to assess the appropriateness of the guidelines.

2. Design. In this step, the course grid was designed based on the students' need as the guideline to develop and manage the tasks of multimedia-based listening materials. Core competences and standard competences was a consideration which underlay English teaching in senior high school. Some materials were added to complete the activities. After the course grid designed, a flowchart was designed to draw the flow and sequence of the multimedia.

3. Development. Development step consist of three steps; material development, expert judgment, and revision.

a. Materials development/the first draft of the materials. multimedia-based listening materials was developed based on the course grid and the flowchart by using Adobe flash software. The multimedia-based listening materials cover three units of the first semester. The process of developing multimedia-based listening materials was encompassing adopting, adapting, and developing.

b. Experts judgment. The multimedia-based listening materials was evaluated by the experts to assess the appropriateness of the multimedia. The categories that evaluated were the content appropriateness of the multimedia and its design appropriateness. The process of assessment was use expert judgment questionnaire.

c. Revision. The result of expert judgment was analyzed and used to revise the first draft of the multimedia-based listening materials. The revision was about the content, the language 
and the presentation. Then, the materials which have been revised became the second draft of the multimedia-based listening materials.

4. Implementation. The second draft of the multimedia-based listening materials was given to the students. The implementation of the materials was conducted to find the quality of the product. During the implementation of the multimedia-based listening materials, the researcher observed the teaching learning process using developed multimedia-based learning materials.

5. Evaluation. The evaluation was conducted to find the quality of the materials. There are some considerations to determine whether the material is good or not. The quality of the material can be seen from the questionnaires which were distributed to the students to get opinion and evaluate the multimedia-based listening materials and from the expert judgment. In addition, the researcher was interview the English teacher to get the response about the implementation of the multimedia-based listening materials. After this step, the researcher revised the materials and end up with the final product.

The data collected were classified into three categories, namely: (1) the result of needs analysis, (2) result of validation stage, and (3) result of the try-out process. The first data were obtained from the market survey, analysis of the students' questionnaire, and an interview with the English teacher. Then, the second data was the outcomes of the evaluation process by the experts including the comments and suggestions for materials improvement. The third data was the students' questionnaires gathered after the process of utilizing the materials.

The instrument to collect the data of the expert validation was in the form of checklist and students' questionnaire following product try out. In addition, the usability and quality of the multimedia was evaluated by the multimedia expert. The result of the product try out was the students' evaluation about the developed materials.

The data collected from market survey was presented descriptively. Then, the students' questionnaires were analyzed quantitatively by using frequency and percentage. The highest percentage was considered as the representation on the students' condition. The next data was an interview with the English teacher. The suggestion and comments were analyzed descriptively to determine the content of the listening materials. The third data came from the expert's judgment on the materials presentation. The result of the expert validation was analyzed quantitatively through descriptive quantitative. The result of the calculation then converted into descriptive analysis that is proposed by Widoyoko (2013) as seen in Table 1.

Table 1: Data Conversion Table

Scale $\quad$ Range $\quad$ Categories




\begin{tabular}{ccc}
\hline 1 & $1 \leq x \leq 1.74$ & Poor \\
2 & $1.75 \leq x<2.24$ & Fair \\
3 & $2.25 \leq x<3.25$ & Good \\
4 & $3.25 \leq x \leq 4$ & Very Good \\
\hline
\end{tabular}

\section{FINDINGS AND DISCUSSIONS}

The developed material or product is in the form of multimedia-based listening materials. It can be accessed from CDs or flash disk. It can also be played without installing additional software to the computer. Therefore, it is quite accessible for the students and teacher.

The supplementary multimedia-based listening materials consist of three units which have different lesson focus. The units were developed mainly based on the result of needs analysis. The needs analysis guided the researcher to develop listening materials for the tenth graders in the first semester using Curriculum of 2013. Due to the time constraint and urgency of the materials, there were only three developed units. Unit 1 talks about descriptive texts, unit 2 discusses recount texts, and unit 3 was about narrative texts. The product of this study can be shown in figure 2.

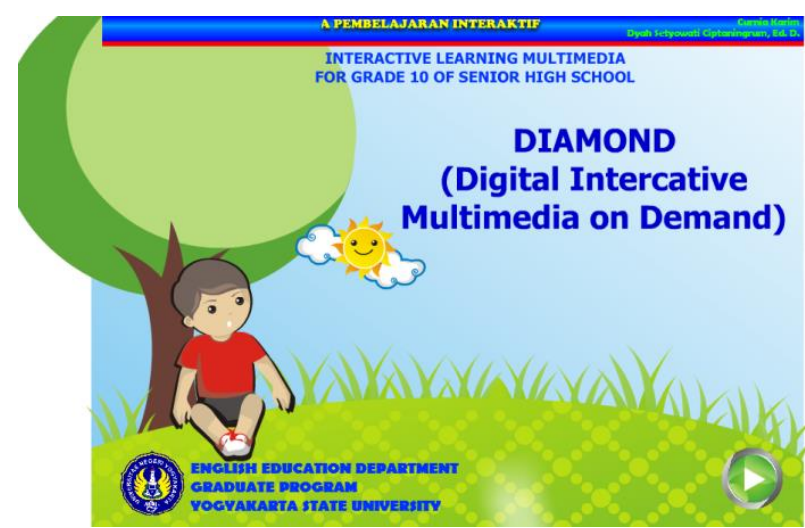

Figure 2: Multimedia-based Listening Materials

Since the product was created for the tenth graders in the first semester and also multimedia-based listening materials, content validation and multimedia validation were carried out. The content validation stage was intended to evaluate the suitability of the listening materials with the syllabus of Curriculum of 2013. While multimedia validation was aimed to check the usability of multimedia features in the materials.

There were some aspects of materials content to be evaluated by the expert of materials. Those aspects were the appropriateness of content, language, activities, and presentation. Meanwhile, the aspects of multimedia to be evaluated by the experts were the appropriateness of screen appearance, multimedia elements, navigation buttons, and feedback. Each criterion is rated by using four different scales, namely: (1) poor, (2) fair, (3) good, (4) very good. The 
total score for materials aspect was 3.3 in scale which is categorized as "very good" criteria, and the total score of media aspect was 3.6 in scale which is categorized as "very good" criteria.

The unit in the developed multimedia-based listening materials are enable students to learn independently and create autonomous learning environment with minimal guidance from the teacher. The materials are good enough for the purpose of autonomous learning because most of the materials let the students do the listening tasks independently and check the answer keys. However, there are some parts that the students need to collaborate with their classmates to share their ideas.

A minor revision on the supplementary multimedia-based listening materials was done for the betterment of the multimedia-based listening materials. The experts' feedback on the content and multimedia design was taken into a consideration to revise the listening materials. After the multimedia-based listening materials was revised based on the experts' suggestion, the product try-out was carried out to check the usability of the multimedia-based listening materials. There were thirty students of MAN 1 Pamekasan involved in the product try-out. They played all the unit from the laptops that were provided by the school. The headphone was also used to help the students listen to the audio in the media clearly. After they played the media and tried to do the listening exercises, they were asked to give response on the questionnaires and suggestions. The questionnaires is rated by using four different scales and the total score for the students' evaluation was 3.68 in scale which is categorized as "very good" criteria.

The students were excited to use the media and complete the listening exercises. Even though they have little difficulties deal with the speech rate of the native speaker, they were eager to answer the listening tasks and check their answers in answer keys. The answer keys assisted them to clarify their answers. The students also found the scoring box as something like reward for them. They were happy when they got a good score. Moreover, all of the students thought that ranges of different kinds of listening exercises were beneficial for them to motivate them to sharpen up their listening skills.

\section{E. CONCLUSION}

The results of the implementation showed that the students were attractive to use the multimedia-based listening materials. The materials provided in the multimedia-based listening materials were well developed. The materials were suitable with the standard of competence and the Basic Competence for tenth grade. Besides, the materials met the students' needs and 


\section{Curnia Karim, Dyah Setyowati, Developing Multimedia-Based Listening...}

the learning objectives. The developed materials were designed based on the students' proficiency level, so that the materials were understandable. Therefore, the materials are expected to be useful for them. Each unit consisted of some tasks or activities which the activities in each unit had been arranged well. Moreover, the materials in multimedia-based listening materials were designed as good as possible, so it was very useful for the students to help them in learning.

The design of the multimedia-based listening materials was simple, so it was not difficult to operate or use the multimedia-based listening materials. The buttons (navigation system) were designed as simple as possible to avoid the students' confusion. As a self-access learning material, it could be operated individually. Supported by those interesting elements, the developed multimedia-based listening materials helped the students to learn listening skill easily, interestingly, and autonomously. Moreover, the multimedia-based listening materials was very useful to motivate the students and keep their attention. It can be concluded that the multimedia-based listening materials was appropriate as a learning medium which can help students to learn listening easily. Additionally, by implementing the multimedia-based listening materials in the learning process, the students will be more motivated. Therefore, the media will keep the students' attention easily.

\section{REFERENCES:}

Branch, R.M. (2009). Instructional Design: The ADDIE Approach. New York: Springer.

Caincross, S., \& Mannion, M. (2001). Interactive Multimedia and Learning: Realizing the Benefits. Innovations in Education and Teaching International, ISSN 1470-3297, DOI: 10.1080/14703290110035428.

Dunkel, P. (1993). Listening in the Native and Second/Foreign Language: Toward an Integration of Research and Practice. State of the Art TESOL Essay. S. Silberstein (Ed), Chicago: Pantagraph Printing.

Field, J. (2008). Listening in the Language Classroom. New York: Cambridge University Press.

Jung, I. S. (2005). A comparative study on the cost-effectiveness of three approaches to ICT teacher training. Journal of Korean Association of Educational Information and Broadcasting, 9 (2). $39-70$.

Kemendikbud. (2013). Materi Pelatiban Guru Implementasi Kurikulum 2013. Kementerian Pendidikan dan Kebudayaan.

Muslimin. (2011). Perlunya Inovasi dalam Pembelajaran Bahasa dan Sastra Indonesia. Jurnal Bahasa, Sastra, dan Budaya, 1.1, 5-6. 
Volume 5, Number 01, June 2019

Nguyen, N., Williams, J., \& Nguyen, T. (2012). The use of ICT in teaching physics: Technology and pedagogy. Asia-Pacific Forum on Science Teaching and Learning, 13(2), 1-19.

O'Connor, J. D. (1998). Better English Pronunciation (Second Edition). University of Cambridge, New York.

Prabbhu. SS, et.al. (2011). PAL: An Intreactive Learning. Platform for Primary. Education. IEEE. International Conference on Technology for Education. Interactive Institut of Information Technology, Banglore India.

Presiden. (2013). Peraturan Pemerintah RI Nomor 65, Tahun 2013, tentang standar proses pendidikan dasar dan menengah.

Presiden. (2013). Peraturan Pemerintah RI Nomor 81A, Tahun 2013, tentang Implementasi Kurikulum.

Richards, J. C., and R. Schimdt. (2010). Longman Dictionary of Language Teaching and Applied Linguistics. London: Longman.

Shank, P. (2005). The Value of Multimedia in Learning. Adobe Design Center [On-line]. Available:http://www.adobe.com/designcenter/thinktank/valuemedia/The_Value_of_ Multimedia.pdf

Spratt, M., Pulverness, A., Williams, M. (2005). The TKT Course: Teaching Knowledge Test. Cambridge: Cambridge University Press.

Stemler, L. K., (1997). Educational characteristics of multimedia: A literature review. Journal of Educational Multimedia and Hypermedia, 6(3/4), 339359.

Ur, P. (1984). Teaching Listening Comprehension. Cambridge: Cambridge University Press.

Vaughan, Tay. (2008). Multimedia: Make It Work 7th Ed. New York: Mc. Graw Hill 